\title{
Chromosome 18
}

National Cancer Institute

\section{Source}

National Cancer Institute. Chromosome 18. NCI Thesaurus. Code C13213.

The designation for each member of the eighteenth largest human autosomal

chromosome pair. Chromosome 18 spans about 76 million base pairs and represents about $2.5 \%$ of the total DNA in normal diploid cells. 